\title{
Fantastic Activity of Those Institutions that Help the Public Hospitals in Leading Those Problematic Pregnancies that Come from Abroad
}

\author{
Juan Piazze ${ }^{1 *}$, Assunta Lombardi ${ }^{2}$, Arianna Amata ${ }^{3}$ and Anna Maria Petitti ${ }^{4}$ \\ ${ }^{1}$ ASL Frosinone (Consultorio Familiare di Frosinone, Casa della Salute di Ceprano, Ospedale SS Trinità di Sora) Frosinone, Lazio, Italy \\ ${ }^{2}$ Social Worker for Region Lazio, Italy \\ ${ }^{3}$ Consultorio Familiare di Frosinone, Italy \\ ${ }^{4}$ ASL Frosinone, Italy
}

Submission: January 25, 2021; Published: January 29, 2021

*Corresponding author: Juan Piazze, ASL Frosinone (Consultorio Familiare di Frosinone, Casa della Salute di Ceprano, Ospedale SS Trinità di Sora) Frosinone, Lazio, Italy

Keywords: Pregnancy; Primary care institutions; Public health service

\section{Introduction}

Our usual clinical activity, always frenetically ongoing, makes us lose the sense of some health operators that help, even further than their actual mission, those women coming from abroad, from other lands. Those women that leave the land that grew them up, usually scaping from unbelieveable situations and even risking their lives in every second since they decided to run away towards unknown territories, where they not only have the difficulties regarding a new language, other meals, other ways of living and behaviour.

Even the religion is different. The different ONLUS programs (social utility no profit organization) and the social organizations working together with regional prefectures, act as a link between these women and the public institutions. And their important role must be emphasized as they represent an important chain in the follow-up and birth of these pregnancies, and most of the times, even in the infants care afterwards. We selected three interesting cases, among the universe that reaches our Department, that may make an idea of these cases helped by the different charity organizations.

\section{Case Presentation}

Sunshine. She arrived from Nigeria at19 years old, with that kind expression in her face that involved questions with no answers in her life. She was among a 50 persons group just arrived in one of those "searchig future trips", crossing the seas in improvised and dangerous boats. The first questions trying to decifrate her nigerian english, and she solved every question taking her hand to the abdomen: meant she was not alone in this trip. The following day with the help of another worker who translated her mother language, was easier to understand what pushed her to risk trying to protect that baby inside of her.

Her family living in Benin City two years ago, made her marry an old man, the richman of the town, who was usually traveling because of working exigencies. Because of this situation, the time spent with Sunshine was minimal, and the oldman, with a sick obsession, pushed her to her wife's "duties". By 2017 Sunshine remained pregnant. When she made everybody know about this pregnancy, the reaction was insults, kicks, humiliation and segregation, since they all believed that the baby did not belong to the old richman. But she did not even immagine what was the next treatment; that night her husband together with his brothers punished her with any kind of violence and aggression. All justified by the sin of betrayal inflicted. The most horrible was still to come, the oldman's mother embellished her face with two deep cuts, in order to make everybody know that Sunshine was nothing. Afterwards, she was thrown in the middle of the street with no money in her pocket. The good heart of one of her neighboors, 
made possible the healing of her scars, offering her a place to live; until she was sent to Libia where she lived in a kind of jail. The release from this prision was possible thanks to an Arabian man, who after the payment, became his master with the aim of selling her to some slave trafficants who would take her to Italy. After two days of navigation through the seas in the worst human conditions, she arrived to Lampedusa near Sicily.

She was taken to the Family Care Division where an ultrasound scan defined a single pregnancy at about 22 wks gestation, apparently uneventful. In the following controls, a placental detachment was diagnosed at about 36 wks gestation, and all the expenses and outward care was supported by one charity institution until the birth was performed in the Hospital at 38 weeks gestation. A baby male was born, with no complications and good weight and general conditions. Sunshine had an uneventful after pregnancy period and every successive control confirmed a healthy status. Now Luke and Sunshine live together. Unfortunately, Sunshine lives with an eternal fear and primary anxiety, she does not permit any male figure to come close to her.

Fatoumata. She come from Costa D'Avorio. We underline that refugees requests are not frequent from this country, and that she traveled alone among other hope searchers coming from Somalia and Mali. She wore an integral dark dress, the kind of those that hide any form or linement behind. And her pregnancy was perfectly hiden. She arrived to Italy knowing a couple of words in french (her mother language was the Bambara). At the age of nine years old, she met her husband, an aunt's friend about 50 years old. One can only imagine that little baby white dressed not understanding the others' relatives happiness. At the age of 14 she got officially married and went to live with her "husband". When she began to understand, cried the all the way long while she was taken to Abijan where the oldman was waiting for her. What followed was a series of violent rape episodes, at any time of the day for a long time. Very soon she remained pregnant, and this fact did not stop her husband to rape her in a disgusting and violent way. In about seven years of hell, she was forced to sell clothes at the market, and when her husband thought she had sold and earned few money, she undressed and beated her in public. In all these years, she remained pregnant four times, and two pregnancies ended in spontaneous abortions.

She at this point, decided to scape, with the help of her mother and one cousin (who would travel together to her), to Libia, taking with her one of her sons. Not just arrived, she understood that the the people that she thought would have helped her, actually were waiting for her in order to exploit her sexually. Her refusal to this violence was continuously punished with hunger and violent physical aggressions. No one protected her and her child, and after some months, she remained again pregnant. After a failed abortion induction, she was sold to one slave trafficant and addressed to Italy, over a rubber dinghy. After arriving in Italy, and considering her advacend pregnancy situation, a charity program accepted her as a priority subject. She come to our ultrasound Division for her first control in pregnancy. A 38 wks' gestation single prenancy was calculated by biometry evaluation, and after the routine blood analyis, an overwhelming new became evident: she was positive to AIDS tests. We decided to relocate her in the program planned for AIDS affected pregnants in one first level public Hospital. Fortunately Amidou, the newborn, has not contracted the infection. And Fatoumata has learned to follow medical controls and takes responsibly the antiretroviral therapy.

Fhaisa. She scaped the horrors of war, and the hell that represented her country, Somalia. You should carry weapons with you if you want to survive the dangerous jungle. One word said "out of the line" and you risk your own life. That was the situation she usually lived. Young male gangs turned around the cities commiting any kind of sin, facilitated by rivers of alcohol and clouds of other drugs. Fatoumata told us that in order to save females' lives, they were hidden in safe places such as the mosques. She had the advantage to belong to a rich family, and this condition permitted her to pay the trip towards Italy. At the beginning quiet and in an uneventful status living under the protection of one charity program, one morning she complained a terrible pain coming from the genital apparatus. Taken to an emergency institution, a infective condition that emerged from an early infibulation was diagnosed. After the antibiotic cures, she was informed about the possibility of dinfibulation surgical procedures, with forefront techniques in order to overcome the physical mutilations. She refused since the beginning any kind of surgical resolution, due to her roots, believes, that were greater than the pain and future infective risks. She represents a case of perseverance, and she remained at the charity Centre, suffering continuously and rising everyday a severe infection.

\section{Comment}

Reviewing bibliography, the private charity related to public health service, has always been a mechanism to consider in order to improve the assistance in this field [1]. The massive immigration that makes desperate people leave their home with the aim to find new horizons in Europe, is a critical situation that involves several countries [2]. These homeless pregnant patients are a vulnerable population, and without the charity institutions, those people would be left to different risky situations. And other useful services are now available for women, i.e., Mission Woman in Rome that is perceived by women victims of violence [3]. There are just few words to comment the three cases we choiced in this report, or maybe we remain speechless. Injustice, violence, transgression, infibulation. Mutilated lives, not only from the physical point of view.

The final comment: an acknowledgment to those people that act in silence, such as a useful army that helps us, the clinical operators of the public health service, to help these desperate people, trying to give a hand, a drop of water in the ocean of 
sufference. All names involved are fictitious in order to respect the individual privacy.

\section{Acknowledgment}

we sincerely thank the omninous help offered by the different social workers of all the charity programs that improve our public health service with their important mission, personalized in Miss Assunta Lombardi: one woman-one army.

\section{References}

1. Schlumbohm J (2014) Private charity-public health service. Comparison between british and german birthing centers of the 18th century. Hist Hosp 29: 46-47.
2. Wang H, Nejtek V, Zieger D, Robinson R, Schrader C, et al. (2015) The role of charity care and primary care physician assignment on ED use in homeless patients. Am J Emerg Med 33(8): 1006-1011.

3. Vencer C, Zicca A, Parasole T, Delle Frate R, Battilana D, et al. (2014) Mission woman: a survey on the perception of the service of welcome and listening offered in the emergency department at the San Camillo Hospital in Rome by women victims of violence. Prof Inferm 67(2): 7585.

\section{Your next submission with Juniper Publishers will reach you the below assets}

- Quality Editorial service

- Swift Peer Review

- Reprints availability

- E-prints Service

- Manuscript Podcast for convenient understanding

- Global attainment for your research

- Manuscript accessibility in different formats

( Pdf, E-pub, Full Tsext, Audio)

- Unceasing customer service

Track the below URL for one-step submission https://juniperpublishers.com/online-submission.php 